Abstracted/indexed in Academic Search Complete, Asia Journals Online, Bangladesh Journals Online, Biological Abstracts, BIOSIS Previews, CAB Abstracts, Current Abstracts, Directory of Open Access Journals, EMBASE/Excerpta Medica, Google Scholar, HINARI (WHO), International Pharmaceutical Abstracts, Open J-gate, Science Citation Index Expanded, SCOPUS and Social Sciences Citation Index;

ISSN: $1991-0088$

\title{
Cardioprotective effect of amlodipine in oxidative stress induced by experimental myocardial infarction in rats
}

\author{
Sudhira Begum and Nargis Akhter \\ Department of Pharmacology, Bangabandhu Sheikh Mujib Medical University, Shahbag, Dhaka 1000 \\ Bangladesh.
}

\begin{tabular}{|c|c|}
\hline Article Info & \\
\hline Received: & 22 December 2006 \\
\hline Accepted: & 30 January 2007 \\
\hline Available Online: & 3 January 2008 \\
\hline DOI: 10.3329/bjp.v & $2 \mathrm{i} 2.570$ \\
\hline $\begin{array}{l}\text { Cite this article: } \\
\text { Begum S, Akhter } \\
\text { effect of amlodi } \\
\text { stress induced by } \\
\text { cardial infarction i } \\
\text { Pharmacol. 2007; } 2\end{array}$ & $\begin{array}{l}\text { J. Cardioprotective } \\
\text { ine in oxidative } \\
\text { experimental myo- } \\
\text { rats. Bangladesh J } \\
55-60 \text {. }\end{array}$ \\
\hline
\end{tabular}

\begin{abstract}
The present study investigated whether the administration of amlodipine ameliorates oxidative stress induced by experimental myocardial infarction in rats. Adrenaline was administered and myocardial damage was evaluated biochemically [significantly increased serum aspertate aminotransferase (AST), lactate dehydrogenase (LDH) and malondialdehyde (MDA) levels of myocardial tissue] and histologically (morphological changes of myocardium). Amlodipine was administered as pretreatment for 14 days in adrenaline treated rats. Statistically significant amelioration in all the biochemical parameters supported by significantly improved myocardial morphology was observed in amlodipine pretreatment. It was concluded that amlodipine afforded cardioprotection by reducing oxidative stress induced in experimental myocardial infarction of catecholamine assault.
\end{abstract}

\section{Introduction}

Cardiovascular diseases (CVDs) are the major health problem of advanced as well as developing countries of the world (Debashis et al., 2004). In Bangladesh CVD is an emerging health problem. Prevalence study in our country is few. In one survey Mohibullah et al. (1998) studied the pattern of CVDs for a period of 1992-97 in a local hospital, Dhaka. They concluded that all types of cardiac diseases are found in Bangladesh. Hypertension is the common cardiac disease followed by ischemic heart disease (IHD). About $50 \%$ of the total admission in the cardiology unit was of coronary artery diseases and male-female ratio is 3.9:1. In 2002, the WHO estimated that $12.6 \%$ of deaths worldwide were from IHD.

Catecholamines in large doses produce myocardial necrosis. Since catecholamine readily undergoes oxidation and the oxidation products of catecholamine are responsible for myocardial damage (Singal et al., 1981).
Catecholamines have been shown to enhance myocardial oxygen consumption and enhance the extents of myocardial damage during evolving AMI. Higher plasma catecholamine levels within first few hours of AMI subsequently appeared to have greater myocardial damage and higher mortality rates support the concept that catecholamines may in themselves exert a deleterious effect (Kalsberg et al., 1981). The heart is more dependent on a continuous supply of oxygen than are most other tissues of the body since short periods of anoxia during AMI result in loss of contractility and irreversible damage to myocardial tissue (Lemely et al., 1959).

AMI causes a detectable rise in the plasma concentration of enzymes, which are normally concentrated within cardiac cells. The enzymes most widely used in the detection of MI are troponin T and I, creatine kinase (CK), aspertate aminotransferase (AST) and lactate dehydrogenase (LDH). Of these most sensitive and cardio specific enzymes are troponin $\mathrm{T}$ and I and CK- 
MB. Troponin T and I are released within hours and remain elevated for 36 hours and $\mathrm{CK}-\mathrm{MB}$ reaches its peak at 12-14 hours. AST starts to rise about 12 hours after infarction and reaches a peak on the first or second day. LDH starts to rise after 12 hours, reaches a peak after 2 or 3 days and may be elevated for a week (Boon et al., 1999).

Lipid peroxidation and anti-oxidant change and their significance during myocardial injury have provided a new insight in the pathogenesis of heart disease (Yogeeta et al., 2006). The increased level of free radical generating system and malondialdehyde (MDA) and lowered levels of free radical scavenging systems seem to have critical role in ischemic heart condition (Pandry et al., 2000).

From the above discussion it is evident that increased circulating catecholamines induced oxidative stress and antioxidant deficit play a cardinal role in the pathogenesis of oxidative damage of myocardium and SCD. Some anti-oxidants and the ability of some cardioprotective drugs are providing protection against the ischemic myocardial damage (Debashis et al., 2004).

Amlodipine had the most potent anti-oxidant activity as a result of its physicochemical properties. The antioxidant activity of amlodipine is attributed to both of its high lipophilicity and a chemical structure that facilitates proton-donating and resonance-stabilization mechanisms that quench the free radical reaction (Mason et al., 1999).

Third generation dihydropyridine type calcium channel blocker amlodipine may provide protective role by its anti-oxidant property and may prevent SCD in patients who are at risk of AMI. It may reduce myocardial ischemic injury by mechanism that may involve a reduction in myocardial oxygen demand as well as by positively influencing transmembrane $\mathrm{Ca}^{2+}$ influxes during ischemia and reperfusion (Lucchesi et al., 1991).

Therefore, the present study aims at demonstrating the cardioprotective effect of amlodipine in MI. Cardioprotective and anti-oxidant effect of amlodipine was assessed by estimating serum enzymes (AST, LDH) released from necrotic myocardial tissues and measuring the concentration of MDA of myocardial tissue and studying the changes of myocardial histology of rats in experimentally induced myocardial infarction.

\section{Materials and Methods}

\section{Chemicals and reagents}

Reduced glutathione (GSH), 5,5-dithiobis-2-nitro benzoic acid (DTNB) and thiobarbituric acid purchased from Sigma Chemical Company (St. Louis, MO, USA). AST, LDH Kits from RANDOX Laboratory, UK and protein estimation kit was from Human Gmbh, Germany. Adrenaline (Gaco Bangladesh) was purchased from local market and amlodipine was supplied by Square Pharmaceuticals as a gift.

\section{Animals}

Adult rats were aged between 2-3 months of both sexes, weighing between 180-220 g. They were kept in medium sized plastic cages. They were allowed to live at room temperature, fed on standard pellets of rat's food and allowed to drink water ad libitum.

\section{Experimental design}

Experimental animals were divided into $\mathrm{V}$ groups and each group was subdivided into two subgroups. Rats were treated with distilled water $(1 \mathrm{~mL})$ in Group I, adrenaline ( $2 \mathrm{mg} / \mathrm{kg}$ body weight) in Group II and both groups were given subcutaneously daily in a single dose 24 hours apart for 2 consecutive days, amlodipine ( $5 \mathrm{mg} / \mathrm{kg}$ body weight) orally daily for 14 consecutive days then adrenaline was given subcutaneously daily in a single dose 24 hours apart for 2 consecutive days from $15^{\text {th }}$ day in Group III, only amlodipine ( $5 \mathrm{mg} / \mathrm{kg}$ body weight) in Group IV and $40 \%$ alcohol $(1 \mathrm{~mL})$ in Group $\mathrm{V}$ were given orally daily in a single dose for 14 consecutive days, All rats in subgroup (a) were sacrificed 24 hours after the last dose and all rats in subgroup (b) were sacrificed 48 hours after the last dose under light anesthesia. $2 \mathrm{~mL}$ of blood was collected in clean test tube and centrifuged (1,725 x g for $5 \mathrm{~min})$. The serum was obtained for estimation of AST and LDH. The heart was excised and some portion of atria and ventricle were placed in formalin for histology. Another portion of heart was processed for biochemical estimation of MDA concentration.

\section{Estimation of serum AST level}

Serum AST level was estimated using UV method (Mathieu, 1986). The concentration of enzyme was measured in spectrophotometer (Micro Flow Cell Photometer AE-100F ERMA Inc) at wavelength $340 \mathrm{~nm}$.

\section{Estimation of serum LDH level}

This is an optimized method according to recommendations of Deutsche Gesellschaft Fur klinische chemie. Absorbance at $340 \mathrm{~nm}$ and the concentration of enzyme were measured in spectrophotometer (Micro Flow Cell Photometer AE-100F ERMA Inc).

\section{Estimation of MDA}

The extent of lipid peroxidation was estimated by using the thiobarbituric acid method (Hagen et al., 1999). The absorbance was measured using spectrophotometer at $532 \mathrm{~nm}$.

\section{Estimation of protein}

The protein content of tissue homogenate was 
Table I

Showing the effect of pretreatment of amlodipine on serum enzymes and myocardial MDA concentration

\begin{tabular}{|c|c|c|c|c|c|c|}
\hline Parameter & $\begin{array}{c}\text { G I } \\
\text { Vehicle (D/W) } \\
(1.0 \mathrm{~mL}) \\
\mathrm{n}=6\end{array}$ & $\begin{array}{c}\text { G II } \\
\text { Adrenaline } \\
(2 \mathrm{mg} / \mathrm{kg} \\
\text { bw. }) \\
\mathrm{n}=10\end{array}$ & $\begin{array}{c}\text { G III } \\
\text { Amlodipine } \\
(5 \mathrm{mg} / \mathrm{kg} \mathrm{b.w.})+\text { Adrenali- } \\
\text { ne }(2 \mathrm{mg} / \mathrm{kg} \text { bw. }) \\
\mathrm{n}=10\end{array}$ & $\begin{array}{c}\text { G IV } \\
\text { Amlodipine } \\
(5 \mathrm{mg} / \mathrm{kg} \\
\text { bw. }) \\
\mathrm{n}=6\end{array}$ & $\begin{array}{c}\text { G V } \\
40 \% \text { alcohol } \\
\text { mL) } \\
n=6\end{array}$ & $\begin{array}{l}\text { Percentage } \\
\text { of preven- } \\
\text { tion by pre- } \\
\text { treatment of } \\
\text { amlodi- } \\
\text { pine\% }\end{array}$ \\
\hline $\begin{array}{l}\text { Serum AST } \\
(\mathrm{U} / \mathrm{L})\end{array}$ & $203.8 \pm 4.8$ & $492.5 \pm 6.2^{\mathrm{a}}$ & $470.9 \pm 6.2^{b}$ & $212.0 \pm 3.2^{\mathrm{NS}}$ & $209 \pm 3.9^{N S}$ & 7.5 \\
\hline $\begin{array}{l}\text { Serum LDH } \\
(\mathrm{U} / \mathrm{L})\end{array}$ & $696.0 \pm 5.9$ & $1425.6 \pm 6.2^{a}$ & $1395.3 \pm 8.7 b$ & $709.4 \pm 4.2^{\mathrm{NS}}$ & $698.9 \pm 3.3^{\mathrm{NS}}$ & 4.2 \\
\hline $\begin{array}{l}\text { MDA } \\
\text { (nmol/mg } \\
\text { protein) }\end{array}$ & $1.4 \pm 0.04$ & $3.3 \pm 0.03^{a}$ & $2.0 \pm 0.1^{\mathrm{a}}$ & $1.6 \pm 0.5^{\mathrm{NS}}$ & $1.5 \pm 0.04^{\mathrm{NS}}$ & 68.4 \\
\hline
\end{tabular}

Data are expressed as mean $\pm \mathrm{SE}, \mathrm{a}=\mathrm{p}<0.001 ; \mathrm{b}=\mathrm{p}<0.05 ; \mathrm{NS}=$ Not significant; $\mathrm{n}=\mathrm{no}$ of rats; bw. Body weight

Distilled water $(\mathrm{D} / \mathrm{W})$ and adrenaline s.c. 2 injections 24 hours apart. Amlodipine orally daily for 14 consecutive days then adrenaline s.c. 2 injections 24 hours apart from $15^{\text {th }}$ day. Only amlodipine or alcohol orally daily for 14 consecutive days. Comparison was made between G I and G II, G II and G III, G I, G IV and G V

estimated by Lowry's method (1951). Bovine serum albumin $(4 \mathrm{mg} / \mathrm{dL})$ was used as standard.

\section{Histological procedure}

Some portion of atria and ventricle of heart was fixed in $10 \%$ formalin, dehydrated in graded alcohol and embedded in paraffin wax, sectioned at $5 \mathrm{~mm}$ thickness and stained with hematoxylin and Eosin (H \& E) for microscopic examination. Microscopically the lesions of the heart were graded as follows (Rona et al., 1959): Grade 0: No lesion. Grade 1: Fibroblastic swelling or proliferation and accumulation of histiocyte. Grade 2: Edema mottled staining, fragmentation and segmentation of muscle fiber. Grade 3: Vacular and fatty degeneration, granular disintegration and hyaline necrosis of muscle fibers. Marked capillary dilatation with hemorrhage, extensive edema occasionally with a mucoid component caused sequestration of muscle fibers. Grade 4: Confluent lesion throughout the heart. Lesions were similar in characteristics to those in Grade 3.

\section{Statistical analysis}

All the results were appropriately recorded in the computer in a tabulated form. Data were analyzed statistically by unpaired student's t-test. The level of significance was set at $p$ value of 0.05 to 0.001 .

\section{Results}

Serum AST level (mean \pm SE) in the vehicle (distilled water) and adrenaline-treated rats 24 hours after the $2^{\text {nd }}$ injection of vehicle and adrenaline were $203.8 \pm 4.8 \mathrm{U} / \mathrm{L}$ and $492.5 \pm 6.2 \mathrm{U} / \mathrm{L}$ respectively. There was a marked rise in serum AST level in the adrenaline treated group as compared to vehicle (control) and the rise was highly significant $(p<0.001)$. Twenty four hours after the $2^{\text {nd }}$ injection of adrenaline, serum AST level in amlodipine pretreated group was $470.9 \pm 6.2 \mathrm{U} / \mathrm{L}$. There was a decrease in serum AST level in amlodipine pretreated group as compared to only adrenaline treated group and the reduction was significant $(\mathrm{p}<0.05)$. Amlodipine pretreatment prevented the adrenaline induced rise in serum AST level by 7.5\%. The change in serum AST level in only amlodipine or alcohol treated group when compared to vehicle was not statistically significant (Table I). Forty-eight hours after the $2^{\text {nd }}$ injection of adrenaline, serum LDH level in the vehicle and adrenaline treated rats were $696.0 \pm 6.4 \mathrm{U} / \mathrm{L}$ and 1425.6 $\pm 5.4 \mathrm{U} / \mathrm{L}$ respectively. There was a marked rise in serum LDH level in the adrenaline treated group as compared to vehicle (control) and the rise was highly significant $(p<0.001)$. Serum LDH level in amlodipine pretreated group was $1395.3 \pm 8.7 \mathrm{U} / \mathrm{L} 48$ hours after the $2^{\text {nd }}$ injection of adrenaline. Amlodipine pretreatment caused attenuation in serum LDH level as compared to only adrenaline treated group and the attenuation was significant $(p<0.05)$. Treatment with amlodipine prevented the adrenaline-induced rise in serum $\mathrm{LDH}$ level by $4.2 \%$. The change in serum LDH level in only amlodipine or alcohol treated group when compared to vehicle was not statistically significant.

The concentration of MDA of myocardial tissue in vehicle treated group was $1.4 \pm 0.05 \mathrm{nmol} / \mathrm{mg}$ protein and adrenaline treated group was $3.3 \pm 0.04 \mathrm{nmol} / \mathrm{mg}$ protein 24 hours after the $2^{\text {nd }}$ injection of vehicle and adrenaline respectively. There was a marked rise in concentration of MDA of myocardial tissue in adrenaline treated group as compared to vehicle and the rise was highly significant $(p<0.001)$. Twenty-four hours after the $2^{\text {nd }}$ injection of adrenaline, the concentration of MDA of heart in amlodipine pretreated group was $2.0 \pm 0.1 \mathrm{nmol} / \mathrm{mg}$ protein. The change of concen- 


\begin{tabular}{|c|c|c|}
\hline \multicolumn{3}{|c|}{ Table II } \\
\hline \multicolumn{3}{|c|}{ Showing the percent of lesion after pretreatment with amlodipine in adrenaline treated rats } \\
\hline Grade of lesion $(G)$ & Percent of lesion $(\%)$ & Percent of lesion $(\%)$ \\
\hline & $\begin{array}{l}\text { Adrenaline treated } \\
\qquad(\mathrm{n}=10) \%\end{array}$ & $\begin{array}{l}\text { Amlodipine + Adrenaline treated } \\
\qquad(\mathrm{n}=10) \%\end{array}$ \\
\hline G 0 & --- & 60 \\
\hline G 1 & 30 & 20 \\
\hline G 2 & 40 & 20 \\
\hline G 3 & 30 & --- \\
\hline
\end{tabular}

$\mathrm{n}=$ No of rats in the group. Adrenaline at a dose of $2 \mathrm{mg} / \mathrm{kg}$ bw S.C. two injections 24 hours apart. Amlodipine pretreatment at a dose of $5 \mathrm{mg} / \mathrm{kg}$ bw orally daily for 2 weeks and then 1 st injection of adrenaline was given on $15^{\text {th }}$ day and $2^{\text {nd }}$ injections after 24 hours

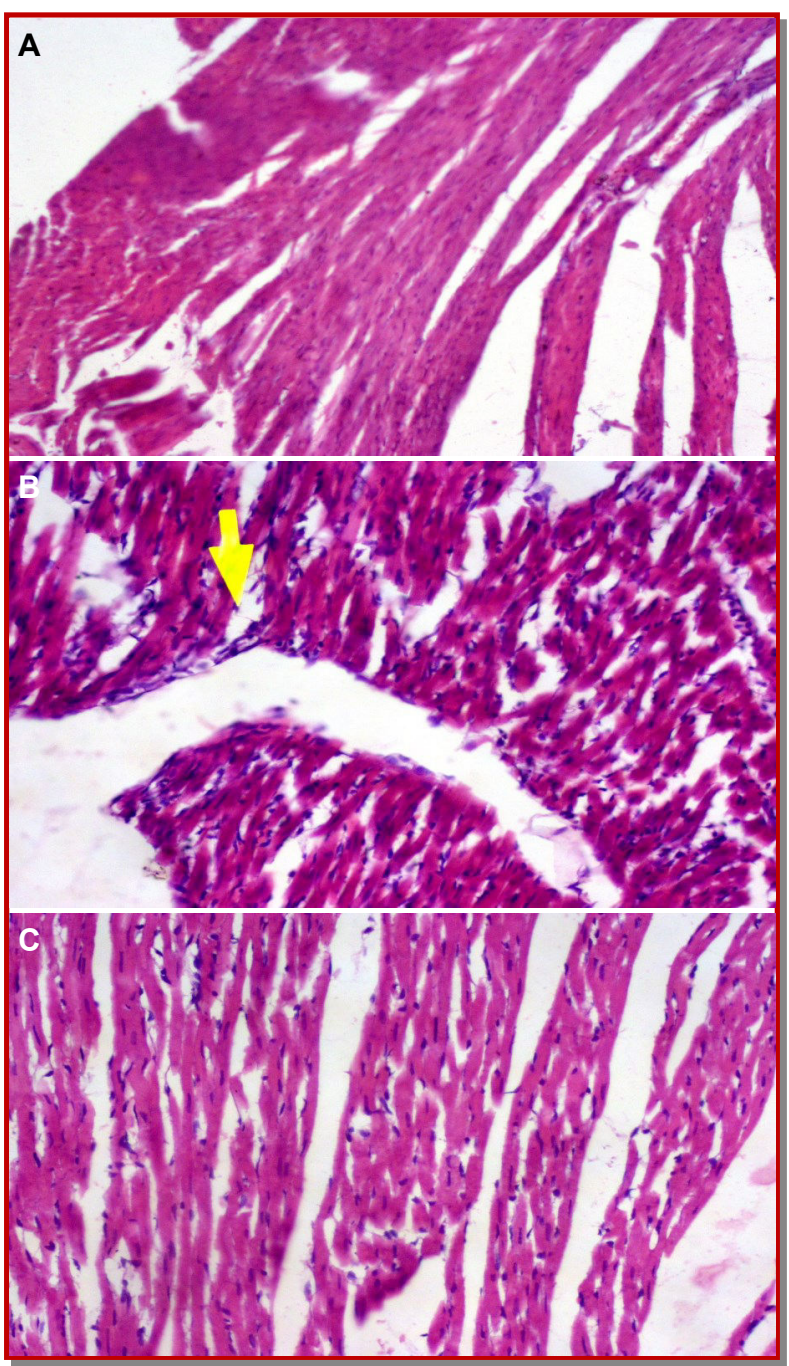

Figure 1: Representative photograph of sections of myocardium under light microscope of rats treated with either distilled water (A), adrenaline (2 mg/ $\mathrm{kg}$ /day for 2 days) (B) and amlodipine $(5 \mathrm{mg} / \mathrm{kg} /$ day for 14 days) plus adrenaline (from $15^{\text {th }}$ day, 2 injection 24 hours apart) (C). H \& E $20 x$ tration of MDA in amlodipine pretreated group as compared to only adrenaline treated group was highly significant $(\mathrm{p}<0.001)$. Amlodipine pretreatment caused $68.4 \%$ prevention of rise of MDA concentration of myocardial tissue was found in adrenaline treated rats. The change in concentration of MDA level in only amlodipine or alcohol treated group was not statistically significant as compared to vehicle.

Normal architecture of the myocardium was observed with no evidence of microscopic changes in the vehicle treated group (Table II and Figure 1). In adrenaline treated heart histological changes such as- mononuclear cellular infiltration, mottled staining, interstitial edema, fragmentation and segmentation of muscle fiber, vacuolar degeneration, capillary dilatation, hemorrhage and congestion of the myocardium were seen. Twenty-four hours after the $2^{\text {nd }}$ injection of adrenaline 30\% animals showed Grade (G 1) lesion, 40\% showed G 2 lesions and $30 \%$ animals showed G 3 and 4 lesions. The microscopic changes were graded according to Rona et al. (1959). Microscopically cellular change in amlodipine pretreated group was less as compared to only adrenaline treated group. The histological changes such as mononuclear cellular infiltration, mottled staining, interstitial edema, fragmentation and segmentation of muscle fiber, vacuolar degeneration and capillary dilatation were reduced after pre treatment with amlodipine. The myocardium regained its histological architecture resembling near normal. After pretreatment with amlodipine 24 hours after the $2^{\text {nd }}$ injection of adrenaline $20 \%$ animals showed Grade (G 1) lesion and 20\% animals showed $G 2$ lesion. Changes like hemorrhage, congestion, vacuolar degeneration, extensive edema ( $G$ 3 and 4) were absent in amlodipine pretreated group.

\section{Discussion}

In this investigation the evidence of experimental MI was assessed by the estimation of serum AST 
and LDH levels and changes in the myocardial morphology. In the present investigation, we also measured concentration of MDA of myocardial tissue for the evidence of free radical induced myocardial damage in experimental MI.

In the present study, serum AST and LDH levels were increased significantly after adrenaline administration. Our result is in agreement with other investigator's findings. Previously Rahman, (2007) and Nahar et al. (2004) found significantly elevated serum AST level 24 hours after the onset of experimental MI. This is also in accordance with Khatun et al. (1994) and Khan, (1996). Khatun et al. (1994) found highly significant $(p<0.001)$ elevation of serum $\mathrm{LDH}$ in adrenaline and isoprenaline treated rats 48 hours after the $2^{\text {nd }}$ injection. Histological changes corresponded with the rise in serum enzymes level. In this investigation, MDA concentration of myocardial tissue was also increased after adrenaline administration. Similarly Gupta et al. (2001) found that in CAD patients in those who had a previous MI, the levels of lipid and MDA were significantly higher than those who had no history of MI. Puspha et al. (2005) suggested that reperfusion of the infarct myocardium leads to oxidative stress and there was a highly significant enhancement in the level of MDA. In this study, all the changes support the fact that adrenaline produced severe necrosis of the myocardium in the doses used in the present experiment.

In the present investigation 2 weeks pretreatment of amlodipine prevented the adrenaline induced rise in enzyme (AST, LDH) levels and protected the myocardium from adrenaline induced necrotic changes. Our result is in agreement with other investigators' findings. Lovric-Bencic et al. (2004) found that amlodipine treatment reversed the increased plasma AST and LDH levels in doxorubicin-congestive heart failure in rat and mouse. Landmark et al. (1997) stated that the use of calcium channel antagonists at the onset of AMI reduces infarct size, as estimated from $\mathrm{CK}_{\max }$ and

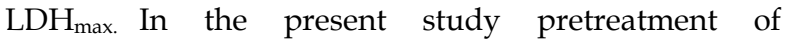
amlodipine in adrenaline treated rats caused significant decrease in myocardial MDA concentration. This result is similar to those of other investigators (Isil et al., 2004; Mason et al., 1999; Gutsura, 2004).

The result of this study indicates that adrenaline administration induced myocardial damage as evidenced by increases in serum AST and LDH levels as well as histomorphological changes in the myocardium which was associated with free radical production as reflected by an increment in MDA concentration in myocardial tissue. Amlodipine afforded cardioprotection by reducing oxidative stress induced in experimental myocardial infarction through prevention of free radical mediated injury of catecholamine assault.

In this study, the cardioprotective effect of amlodipine has been assessed. Further study is suggested to evaluate the role of amlodipine in the treatment of MI.

\section{References}

Boon NA, Fox KAA, Bloomfield P. Disease of cardiovascular system. In. Haselett C, Chilvers ER, Hunter JAA, Boon NA, (eds). Davidson's Principles and practice of medicine $18^{\text {th }}$ edn. Edinbergh, Churchill Livingstone, 1999, pp 191.

Debashis B, Aindrila C, Goutam G, Asoke GD. Oxidative stress -induced ischemic heart disease protected by anti-oxidant. Curr Med Chem. 2004; 11: 369-87.

Gatsura SV. Oxygen-dependent mechanisms underlying the antiischemic effect of verapamil and amlodipine. Bull Exp Biol Med. 2004; 137: 40-42.

Gupta M, Chari S. Lipid peroxidation and anti-oxidant enzymes in coronary and peripheral artery disease. Indian J Med Sci. 2001; 55: 79-82.

Hagan TM, Inger Soll RT, Laykkesfeld J, Liu J, Wehr CM, Vinarsky V, Bartholomew JC, Ames BN. (R)-2- Lipoic acid supplemented old rats have improved mitochondrial function, decreased oxidative damage and increased metabolic rate. FASEB J. 1999; 13: 411-18.

Isil M, Sara H, Nevbahar T, Zuhal P, Dilek O, Oya B, Aysegul U. Amlodipine and glutathione cycle in hypercholesterolaemia. Acta Cardiologica. 2004; 59: 485-92.

Karlsberg RP, Cryer PE, Roberts R. Serial plasma catecholamine response early in the course of clinical acute myocardial infarction: Relationship to infarct extent and mortality. Am Heart J. 1981; 102: 24-29.

Khan I. Effect of anti-oxidant vitamin $\mathrm{E}$ and $\mathrm{C}$ on adrenaline induced myocardial damage in rats. M. Phil Thesis, Dhaka, University of Dhaka, 1996.

Khatun M, Chowdhury SAR, Misbahuddin M. Infarct like myocardial lesion produced by catecholamine in rat. Bangladesh J Physiol Pharmacol. 1996; 12: 4-5.

Landmark K, Abdelnoor M, Kilhovd B, Dorum HP. Infarct size as estimated from peak creatine kinase and lactate dehydrogenase is probably reduced in patients using calcium antagonists at the onset of symptoms. Cardiovasc Drugs Ther. 1997: 11: 557-65.

Lemely JM, Meneely GR. Effect of anoxia on metabolism of myocardial tissue. Am J Med. 1952; 2: 66-73.

Lovric-Bencic M, Sikiric P, Hanzevacki LS, Seiwerth S, Rogic D, Kusec V, Aralica G, Konjevoda P, Batelja L, Blagaic AB. Doxorubicine-congestive heart failure-increased big endothelin-1 plasma concentration: Reversal by amlodipine, losartan and gastric pentadecapeptide BPC157 in rats and mouse. J Pharmacol Sci. 2004; 95: 19-26.

Lowary $\mathrm{OH}$, Rosenbrough NJ, Farr AL, Randall RJ. Protein measurement with the folin Phenol reagent. J Biol Chem. $1951 ; 265-75$.

Lucchesi BR, Hoff PT, Tamura Y. Cardioprotective effects of amlodipine in animal models of ischemia and reperfusion. J Cardiovasc Pharmacol. 1991; 1: 34-39. 
Mason RP, Mak IT, Trumbore MW, Mason PE, Milton P, Alan M. Anti-oxidant properties of calcium antagonists related to membrane biophysical interactions. Am J Cardiol. 1999; 84: $16-22$.

Mathieu M. IFCC method for L-Aspertate aminotransferase. J Clin Chem Clin Biochem. 1986; 24: 497-510. Cited by BIOLAB in document provided with AST (GOT) IFCC Single Vial Method. Package 80125.

Mohibullah AKM, Hossain MFA, Chowdhury FI, Islam MN. Pattern of cardiovascular diseases in Sir Salimullah Medical College and Mitford Hospital, Dhaka a six year study. Sir Salimullah Med Coll J. 1998; 6: 13-16.

Nahar N, Akhter N, Rahman MS. Protective role of carvidilol in experimental myocardial infarction. Bangladesh J Physiol Pharmacol. 2004; 20: 9-12.

Pandry NR, Kaur G, Chandra M, Sanwal GG, Misra MK. Enzymatic oxidant and anti-oxidants of human blood platelets in unstable angina and myocardial infarction. Int J Cardiol. 2000; 76: 33-38.
Pushpa B, Chandra M, Misra WK. Oxidative stress parameters in erythocytes of post-reperfused patients with infarction. J Enz Inhib Med Chem. 2005; 20: 377-81.

Rahman W. Role of nonselective beta-blockers in the prevention of adrenaline induced cardiac damage following myocardial infarction. M. Phil Thesis Dhaka, BSMMU, 2007.

Rona G, Chappel CL, Balazs T, Gaudry R. An infarct like myocardial lesion and other toxic manifestations produced by isoproterenol in the rat. AMA Arch Pathol. 1959; 67: 44355.

Singal PK, Kapur N, Dhillon KS, Beamish RE, Dhalla NS. Role of free radicals in catecholamine-induced cardiomyopathy. Can J Physiol Pharmacol. 1981; 60: 1390-97.

Yogeeta SK, Gnanapragasam A, Kumar SS, Subhashini R, Sathivel A, Devaki T. Synergistic interactions of ferulic acid with ascorbic acid: Its cardioprotetive role during isoproterenol-induced myocardial infarction in rats. Mol Cell Biochem. 2006; 283: 139-46.

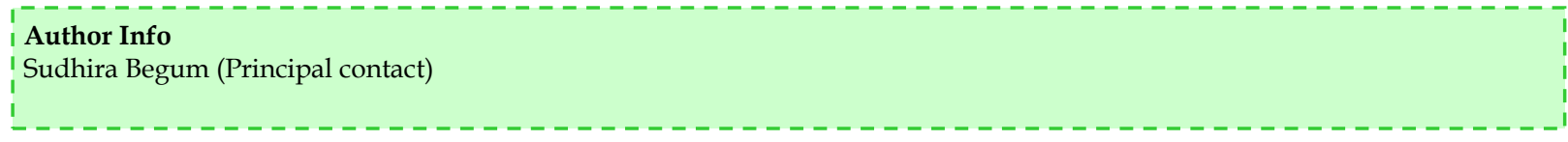

